\title{
Streptomyces axinellae sp. nov., isolated from the Mediterranean sponge Axinella polypoides (Porifera)
}

\author{
Sheila Marie Pimentel-Elardo, ${ }^{1,2}$ Matthias Scheuermayer, ${ }^{1,2}$ \\ Svitlana Kozytska ${ }^{1,2}$ and Ute Hentschel ${ }^{1,2}$ \\ ${ }^{1}$ Research Center for Infectious Diseases, University of Würzburg, Röntgenring 11, D-97070 \\ Würzburg, Germany \\ ${ }^{2}$ Julius-von-Sachs Institute for Biological Sciences, University of Würzburg, Julius-von-Sachs Platz \\ 3, D-97082 Würzburg, Germany
}

Correspondence

Ute Hentschel

ute.hentschel@uni-wuerzburg.de

\begin{abstract}
An actinomycete strain, isolated from the marine sponge Axinella polypoides collected from Banyulssur-Mer, France, was characterized using a polyphasic approach. Based on its chemotaxonomic and morphological characteristics, strain Pol001 ${ }^{\top}$ belongs to the genus Streptomyces. The strain is characterized by LL-diaminopimelic acid in the cell wall, menaquinones MK- $9\left(\mathrm{H}_{4}, \mathrm{H}_{6}, \mathrm{H}_{8}\right)$ and a DNA $\mathrm{G}+\mathrm{C}$ content of $71.0 \mathrm{~mol} \%$. It forms a separate phyletic line based on phylogenetic analyses of the nearly complete $16 \mathrm{~S}$ rRNA gene sequence. Strain $\mathrm{Pol00}{ }^{\top}$ could be differentiated from other closely related Streptomyces species with validly published names by phenotypic and genotypic analysis. DNA-DNA hybridization between strain $\mathrm{Pol001}^{\top}$ and closely related reference strains further confirmed that strain $\mathrm{Pol001^{ \top }}$ represents a novel taxon of the genus Streptomyces. Therefore, it is proposed that strain Pol001 ${ }^{\top}$ represents a novel species in the genus Streptomyces, Streptomyces axinellae sp. nov.; the type strain is $\mathrm{Pol001}^{\top}\left(=\mathrm{DSM} 41948^{\top}=\mathrm{CIP} 109838^{\top}\right)$.
\end{abstract}

The genus Streptomyces was proposed by Waksman \& Henrici (1943) for aerobic, spore-forming actinomycetes. These Gram-positive bacteria have distinct features such as extensively branching substrate and aerial mycelia, a high DNA G + C content (69-78 mol\%) and the presence of LLdiaminopimelic acid ( $\left.\mathrm{LL}-\mathrm{A}_{2} \mathrm{pm}\right)$ and the absence of characteristic sugars in the cell wall (Anderson \& Wellington, 2001). The genus Streptomyces currently contains more than 500 species and subspecies with validly published names, making this genus the largest in the domain Bacteria (Hain et al., 1997). In this study, cultivation and characterization of strain $\mathrm{Pol}_{001}{ }^{\mathrm{T}}$, which exhibits properties that are consistent with its assignment to the genus Streptomyces, are described.

Strain Pol001 ${ }^{\mathrm{T}}$ was isolated from the Mediterranean sponge Axinella polypoides. The sponge was collected by scuba diving offshore from Banyuls-sur-Mer, France (GPS: $42^{\circ}$ $29^{\prime} \mathrm{N} 03^{\circ} 08^{\prime} \mathrm{E}$ ) in May 2003. Mechanical separation of the sponge tissue and storage of bacterial cells were performed as described by Fieseler et al. (2004). M1 medium, containing [per litre artificial seawater (ASW)] $10 \mathrm{~g}$ starch, 4 g yeast extract and 2 g peptone (Mincer et al., 2002), was used to cultivate the strain. ASW contained the following

Abbreviations: $A_{2}$ pm, diaminopimelic acid; ASW, artificial seawater. The GenBank/EMBL/DDBJ accession number for the 16S rRNA gene sequence of strain PolO01 ${ }^{\top}$ is EU683612. salts $\left(1^{-1}\right): \mathrm{NaCl}, 23.477 \mathrm{~g} ; \mathrm{MgCl}_{2} \cdot 6 \mathrm{H}_{2} \mathrm{O}, 10.64 \mathrm{~g} ; \mathrm{Na}_{2} \mathrm{SO}_{4}$, 3.917 g; $\mathrm{CaCl}_{2}, 1.102 \mathrm{~g} ; \mathrm{KCl}, 0.664 \mathrm{~g} ; \mathrm{NaHCO}_{3}, 0.192 \mathrm{~g}$; $\mathrm{KBr}, 0.096 \mathrm{~g} ; \mathrm{H}_{3} \mathrm{BO}_{3}, 0.026 \mathrm{~g} ; \mathrm{SrCl}_{2}, 0.024 \mathrm{~g}$; and $\mathrm{NaF}$, 0.03 g (Lyman \& Fleming, 1940).

Cultural characteristics were observed on a number of standard media (Shirling \& Gottlieb, 1966). Strain Pol001 ${ }^{\mathrm{T}}$ grew well on a variety of standard International Streptomyces Project (ISP) agar media after incubation at $30{ }^{\circ} \mathrm{C}$ for 21 days: yeast-malt extract (ISP2), oatmeal (ISP3) and peptone-yeast extract-iron (ISP6). A diffusible pigment was observed only on tyrosine agar (ISP7) (Table 1). Grey aerial and white substrate mycelia were abundant on ISP2 medium. The strain was further examined for a range of phenotypic and physiological properties using standard procedures (Gottlieb, 1961; Shirling \& Gottlieb, 1966; Korn-Wendisch et al., 1989). Strain Pol001 ${ }^{\mathrm{T}}$ was positive for gelatin liquefaction, but negative for melanin production, starch hydrolysis, nitrate reduction and hydrogen sulfide production. The strain was able to degrade casein, but not adenine, chitin or hypoxanthine. Growth in ISP2 broth was tested at 20, 25, 30, 37, 42 and $55{ }^{\circ} \mathrm{C}$. Strain Pol001 ${ }^{\mathrm{T}}$ was able to grow at $20-37{ }^{\circ} \mathrm{C}$, with optimum growth at $30^{\circ} \mathrm{C}$. ISP2 media supplied with different amounts of $\mathrm{NaCl}$ and $\mathrm{ASW}$ were used to test for salt tolerance and seawater requirements. Growth was possible in $0,2.5,5.0$ and $7.5 \% \mathrm{NaCl}$, but not in $10.0,12.5$ or $15.0 \% \mathrm{NaCl}$, with optimal growth at $0-2.5 \% \mathrm{NaCl}$. 
Table 1. Cultural characteristics of strain $\mathrm{Pol}_{001}{ }^{\top}$ on various agar media

\begin{tabular}{|lcccc|}
\hline Medium & Growth & Diffusible pigment & Aerial mycelium & Substrate mycelium \\
\hline Yeast-malt extract (ISP2) & Abundant & None & Grey & White \\
Oatmeal (ISP3) & Abundant & None & Dark brown & Light green \\
Inorganic salts-starch (ISP4) & Poor & None & Yellow-orange & White \\
Glycerol-asparagine (ISP5) & Moderate & None & White & Light yellow \\
Peptone-yeast extract-iron (ISP6) & Abundant & None & Light pink & Light green \\
Tyrosine (ISP7) & Moderate & Red & Light pink to black & Light green \\
Czapek's medium & Abundant & None & White & White \\
Nutrient agar & Abundant & None & & \\
\end{tabular}

Growth was also possible in ISP2 medium with 25, 50, 75 and $100 \%$ ASW. Furthermore, strain Pol001 ${ }^{\mathrm{T}}$ was able to grow in medium supplemented $\left(100 \mu \mathrm{g} \mathrm{ml}^{-1}\right)$ with the antibiotics ampicillin, chloramphenicol, nalidixic acid, penicillin and rifampicin, but not with erythromycin, gentamicin, kanamycin or vancomycin. Utilization of different carbon sources was tested using Biolog SF-P2 following the manufacturer's instructions (Biolog); data are given in the species description. The morphological, physiological and biochemical characteristics of strain Pol001 $1^{\mathrm{T}}$ and phylogenetically related Streptomyces species are shown in Table 2.

Determination of the genomic DNA $\mathrm{G}+\mathrm{C}$ content and diagnostic cell-wall components was performed by the Identification Service of the Deutsche Sammlung von Mikroorganismen und Zellkulturen (DSMZ), Braunschweig, Germany. The $\mathrm{G}+\mathrm{C}$ content of the genomic DNA of strain Pol001 ${ }^{\mathrm{T}}$, determined by HPLC (Mesbah et al., 1989; Tamaoka \& Komagata, 1984), was $71.0 \mathrm{~mol} \%$. Established procedures were used to determine the diagnostic isomer of
$\mathrm{A}_{2} \mathrm{pm}$ and the predominant sugars of the whole organism (Staneck \& Roberts, 1974). Strain Pol001 ${ }^{\mathrm{T}}$ contained LL$\mathrm{A}_{2} \mathrm{pm}$ in the cell wall. Analysis of the whole-cell sugar composition revealed the presence of glucose and ribose, as well as traces of mannose. Quinone analysis was carried out as described by Kroppenstedt (1985). A menaquinone with a hexahydrogenated-isoprenoid side chain of nine units, MK$9\left(\mathrm{H}_{6}\right)$, was found as the principal isoprenoid quinone. Two additional quinones with nine isoprene units [MK-9 $\left.\left(\mathrm{H}_{4}, \mathrm{H}_{8}\right)\right]$ were also found. Polar lipids were extracted and analysed following the integrated procedure of Minnikin et al. (1984). Strain Pol001 ${ }^{\mathrm{T}}$ contained the following polar lipids: diphosphatidylglycerol, phosphatidylglycerol, phosphatidylethanolamine, phosphatidylinositol, unidentified phospholipids, phosphoglycolipids, glycolipids and an aminolipid. The fatty acid composition was determined by GC using MIDI software. Strain Pol001 ${ }^{\mathrm{T}}$ contained the following fatty acids: iso- $\mathrm{C}_{16: 0} \quad(30.78 \%)$, anteiso- $\mathrm{C}_{15: 0}(17.77 \%)$, iso- $\mathrm{C}_{15: 0}$ $(12.03 \%)$, anteiso- $\mathrm{C}_{17: 0}(9.80 \%)$, iso- $\mathrm{C}_{16: 1}(6.92 \%)$, iso$\mathrm{C}_{14: 0}(5.77 \%)$ and iso- $\mathrm{C}_{17: 1}(4.58 \%)$.

Table 2. Selected physiological properties that differentiate strain $\mathrm{Pol} 001^{\top}$ from closely related Streptomyces species

Strains: 1 , Pol001 ${ }^{\mathrm{T}}$; 2, S. sclerotialus DSM $43032^{\mathrm{T}}$; 3, S. rimosus subsp. rimosus DSM $40260^{\mathrm{T}}$; 4, S. niger DSM $43049^{\mathrm{T}}$; 5, S. olivaceiscleroticus DSM $40595^{\mathrm{T}}$. Colour of mycelium and reverse side of colony and production of diffusible and melanoid pigments were compared using growth on ISP2 medium. All strains had smooth spore surfaces, utilized glucose, mannitol and fructose as carbon sources and lacked melanoid pigments. Data for reference strains were taken from Shirling \& Gottlieb (1968a, b, 1972). Abbreviations: SP, Spirales; RA, Retinaculiaperti; G, grey; w, white; Y, yellow; R, red; B, brown; L, light; D, dark; +, positive; -, negative; d, doubtful.

\begin{tabular}{|lccccc|}
\hline Characteristic & $\mathbf{1}$ & $\mathbf{2}$ & $\mathbf{3}$ & $\mathbf{4}$ & $\mathbf{5}$ \\
\hline Spore-chain morphology & SP & SP & SP, RA & SP & SP \\
Colour of aerial mycelium & GW & LYR & R or W & YG & BG \\
Reverse side of colony & W & YB & GY & DB & GY \\
Production of diffusible pigment & - & - & - & + & + \\
Utilization of: & - & & & & \\
$\quad$ L-Arabinose & - & + & + & + & + \\
Inositol & - & + & + & + & + \\
Raffinose & - & + & + & + & + \\
Rhamnose & + & + & - & + & + \\
Sucrose & - & + & - & + & + \\
Xylose & + & + & $\mathrm{d}$ & + & + \\
\end{tabular}




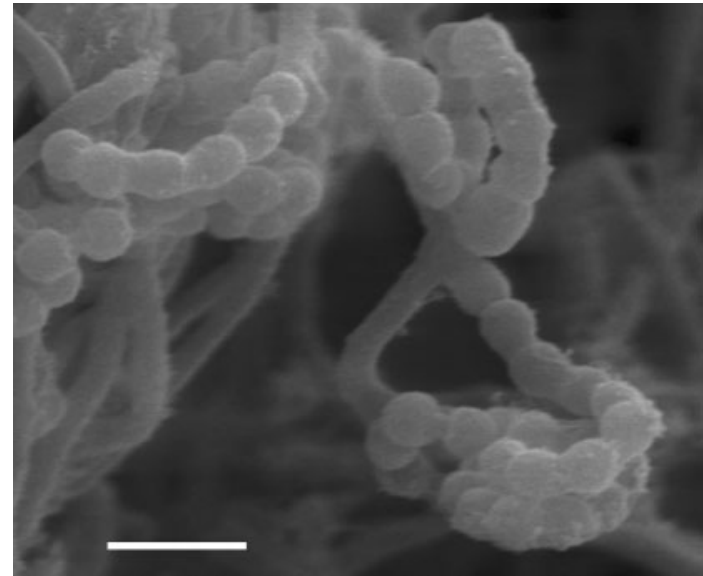

Fig. 1. Scanning electron micrograph of strain $\mathrm{Pol001}{ }^{\top}$ grown on ISP2 at $30{ }^{\circ} \mathrm{C}$ for 21 days. Bar, $2 \mu \mathrm{m}$.

Scanning electron microscopy of strain $\mathrm{Pol}_{001^{\mathrm{T}}}$ was performed as described previously (Scheuermayer et al., 2006). Strain Pol001 $1^{\mathrm{T}}$ exhibited morphological properties that were characteristic of Streptomyces species, forming extensively branched substrate and aerial mycelia without fragmentation. The morphology of the spores and spore chains was described according to Pridham et al. (1958). Scanning electron microscopy revealed long spiral chains of spores with a smooth surface (Fig. 1). The spores were elliptical in shape and $0.8-0.9 \mu \mathrm{m}$ in length.

$16 \mathrm{~S}$ rRNA gene amplification, cloning and sequencing were performed according to the methods of Hentschel et al. (2001) using the universal primers 27f and 1492r (Lane, 1991). An almost-complete $16 S$ rRNA gene sequence (1422 nt) was generated for the strain and compared to sequences of members of the genus Streptomyces with validly published names. The sequences were then aligned using CLUSTAL $\mathrm{W}$ and phylogenetic analysis was performed using the ARB software (Ludwig et al., 2004). Phylogenetic tree construction was performed using the neighbourjoining algorithm with bootstrap values based on 1000 replications (Fig. 2). Phylogenetic analysis revealed that strain Pol001 ${ }^{\mathrm{T}}$ exhibited highest sequence similarities with Streptomyces sclerotialus DSM $43032^{\mathrm{T}} \quad(97.61 \%)$, Streptomyces rimosus subsp. rimosus DSM $40260^{\mathrm{T}}$ $(97.47 \%)$, Streptomyces niger DSM $43049^{\mathrm{T}}(97.20 \%)$ and Streptomyces olivaceiscleroticus DSM $40595^{\mathrm{T}}(97.20 \%)$.

DNA-DNA hybridization between strain $\mathrm{Pol}_{001}{ }^{\mathrm{T}}$ and closely related strains selected on the basis of their $16 \mathrm{~S}$ rRNA gene sequence similarities was carried out by the DSMZ Identification Service. Levels of DNA-DNA relatedness between strain Pol001 ${ }^{\mathrm{T}}$ and the type strains of four closely related species were as follows (means of two values): S. sclerotialus DSM $43032^{\mathrm{T}}, 26.8 \%$; S. olivaceiscleroticus DSM $40595^{\mathrm{T}}$, $16.9 \%$; S. niger DSM $43049^{\mathrm{T}}, 8.75 \%$; and S. rimosus subsp. rimosus DSM $40260^{\mathrm{T}}, 8.65 \%$. The hypothesis for the species concept in the genus

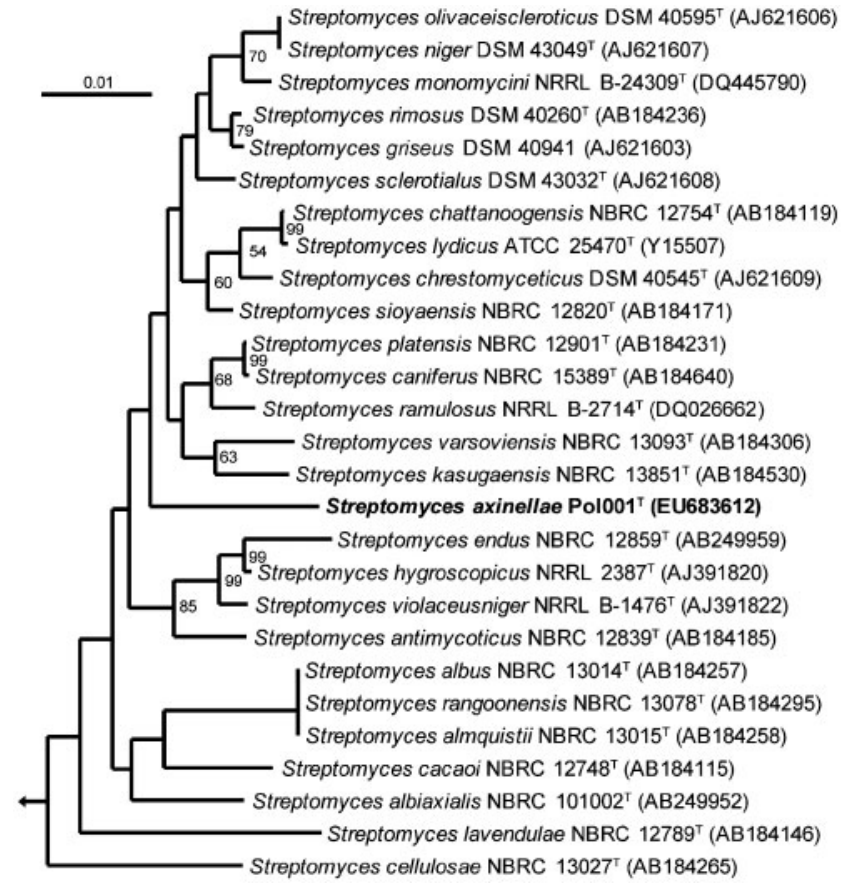

Fig. 2. Neighbour-joining tree of strain $P o l 001^{\top}$ and representative species of the genus Streptomyces based on nearly complete (1422 nt) 16S rRNA gene sequences. Numbers at nodes indicate levels of bootstrap support based on 1000 resampled datasets. Only values greater than $50 \%$ are shown. The arrow points to the outgroup, Salinispora tropica CNB-536 (GenBank accession no. AY040618). Bar, 0.01 substitutions per nucleotide position.

Streptomyces is that strains of the same species have DNA relatedness $>70 \%$ (with a $\Delta T_{\mathrm{m}}$ of $<5{ }^{\circ} \mathrm{C}$ ) (Anderson \& Wellington, 2001; Wayne et al., 1987). The low DNA-DNA relatedness values further confirmed that strain $\mathrm{Pol}_{00}{ }^{\mathrm{T}} \mathrm{can}$ be considered a novel taxon.

Strain Pol001 ${ }^{\mathrm{T}}$ can be differentiated clearly from all other species of the genus Streptomyces with validly published names based on a combination of phenotypic characteristics and genotypic data. It is concluded that Pol001 ${ }^{\mathrm{T}}$ represents a novel species of the genus Streptomyces, for which the name Streptomyces axinellae sp. nov. is proposed.

\section{Description of Streptomyces axinellae sp. nov.}

Streptomyces axinellae (a.xi.nel'lae. N.L. gen. n. axinellae of Axinella, referring to the isolation of the type strain from the marine sponge Axinella polypoides).

Aerobic, Gram-positive actinomycete that forms extensively branched non-fragmenting substrate and aerial mycelia. Spores have a smooth surface and occur in spiral chains. No diffusible pigments are produced except on ISP7 medium. Growth occurs at $20-37{ }^{\circ} \mathrm{C}$ (optimum $30{ }^{\circ} \mathrm{C}$ ) and in ISP2 medium containing 0 $7.5 \% \mathrm{NaCl}$ (optimum $0-2.5 \%$ ) or $0-100 \%$ ASW. Utilizes a variety of organic compounds as carbon 
sources including $N$-acetyl- $\beta$-D-mannosamine, $N$-acetylD-glucosamine, $\mathrm{N}$-acetyl-L-glutamic acid, L-alaninamide, L-alanine, L-alanyl glycine, D-arabitol, cellobiose, dextrin, $\mathrm{D}$-fructose, D-galactose, gentiobiose, D-gluconic acid, $\alpha$-Dglucose, L-glutamic acid, glycerol, DL- $\alpha$-glycerol phosphate, $\alpha$-D-lactose, L-malic acid, D-mannitol, D-mannose, propionic acid, L-rhamnose, D-ribose, L-serine, Tweens 40 and 80 and $\mathrm{D}$-xylose, but not acetic acid, adenosine, AMP, D-alanine, amygdalin, L-arabinose, arbutin, L-asparagine, 2,3-butanediol, $\alpha$ - or $\beta$-cyclodextrin, 2 -deoxyadenosine, D-fructose 6-phosphate, L-fucose, D-galacturonic acid, $\alpha$-Dglucose 1-phosphate, D-glucose 6-phosphate, glycogen, glycyl L-glutamic acid, $\alpha$-, $\beta$ - or $\gamma$-hydroxybutyric acids, $p$ hydroxyphenylacetic acid, inosine, myo-inositol, inulin, $\alpha$ ketoglutaric acid, $\alpha$-ketovaleric acid, lactamide, L-lactic acid, D-lactic acid methyl ester, lactulose, D-malic acid, maltose, maltotriose, mannan, melezitose, melibiose, methyl $\alpha$-D-galactoside, methyl $\beta$-D-galactoside, 3-methyl $\mathrm{D}$-glucose, methyl $\alpha$-D-glucoside, methyl $\beta$-D-glucoside, methyl $\alpha$-D-mannoside, palatinose, D-psicose, putrescine, L-pyroglutamic acid, pyruvic acid, pyruvic acid methyl ester, raffinose, salicin, sedoheptulosan, L-serine, D-sorbitol, stachyose, succinamic acid, succinic acid, succinic acid monomethyl ester, sucrose, D-tagatose, thymidine, TMP, trehalose, turanose, uridine, UMP or xylitol. Positive for gelatin liquefaction, but negative for melanin production, starch hydrolysis, nitrate reduction and hydrogen sulfide production. Able to degrade casein, but not adenine, chitin or hypoxanthine. The cell wall contains $\mathrm{LL}_{-} \mathrm{A}_{2} \mathrm{pm}$. Whole-cell hydrolysates contain glucose, ribose and traces of mannose. Major menaquinone is MK- $9\left(\mathrm{H}_{6}\right)$. Phospholipid pattern consists of diphosphatidylglycerol, phosphatidylglycerol, phosphatidylethanolamine, phosphatidylinositol, some unidentified phospholipids, phosphoglycolipids, glycolipids and an aminolipid. Fatty acid pattern consists of iso- $\mathrm{C}_{16: 0}$, anteiso- $C_{15: 0}$, iso- $C_{15: 0}$, anteiso- $C_{17: 0}$, iso- $C_{16: 1}$, iso- $C_{14: 0}$ and iso- $\mathrm{C}_{17: 1}$.

The type strain is $\operatorname{Pol}_{001}{ }^{\mathrm{T}}\left(=\mathrm{DSM} 41948^{\mathrm{T}}=\right.$ CIP $\left.109838^{\mathrm{T}}\right)$, isolated from the Mediterranean sponge Axinella polypoides. The DNA G + C content of the type strain is $71.0 \mathrm{~mol} \%$.

\section{Acknowledgements}

We gratefully acknowledge H. Angermeier and G. Krohne (U. Würzburg) for assistance with electron microscopy. Financial support was provided by SFB630-TP A5 to U. H.

\section{References}

Anderson, A. S. \& Wellington, E. M. H. (2001). The taxonomy of Streptomyces and related genera. Int J Syst Evol Microbiol 51, 797-814.

Fieseler, L., Horn, M., Wagner, M. \& Hentschel, U. (2004). Discovery of the novel candidate phylum "Poribacteria" in marine sponges. Appl Environ Microbiol 70, 3724-3732.

Gottlieb, D. (1961). An evaluation of the criteria and procedures used in the description and characterization of the streptomycetes: a cooperative study. Appl Microbiol 9, 55-65.
Hain, T., Ward-Rainey, N., Kroppenstedt, R. M., Stackebrandt, E. \& Rainey, F. A. (1997). Discrimination of Streptomyces albidoflavus strains based on the size and number of 16S-23S ribosomal DNA intergenic spacers. Int J Syst Bacteriol 47, 202-206.

Hentschel, U., Schmid, M., Wagner, M., Fieseler, L., Gernert, C. \& Hacker, J. (2001). Isolation and phylogenetic analysis of bacteria with antimicrobial activities from the Mediterranean sponges Aplysina aerophoba and Aplysina cavernicola. FEMS Microbiol Ecol 35, 305-312.

Korn-Wendisch, F., Kempf, A., Grund, E., Kroppenstedt, R. M. \& Kutzner, H. J. (1989). Transfer of Faenia rectivirgula Kurup and Agre 1983 to the genus Saccharopolyspora Lacey and Goodfellow 1975, elevation of Saccharopolyspora hirsuta subsp. taberi Labeda 1987 to species level, and emended description of the genus Saccharopolyspora. Int J Syst Bacteriol 39, 430-441.

Kroppenstedt, R. M. (1985). Fatty acid and menaquinone analysis of actinomycetes and related organisms. In Chemical Methods in Bacterial Systematics (Society for Applied Bacteriology Technical Series vol. 20), pp. 173-199. Edited by M. Goodfellow \& D. E. Minnikin. New York: Academic Press.

Lane, D. J. (1991). 16S/23S rRNA sequencing. In Nucleic Acid Techniques in Bacterial Systematics, pp. 115-175. Edited by E. Stackebrandt \& M. Goodfellow. Chichester: Wiley.

Ludwig, W., Strunk, O., Westram, R., Richter, L., Meier, H., Yadhukumar, Buchner, A., Lai, T., Steppi, S. \& other authors (2004). ARB: a software environment for sequence data. Nucleic Acids Res 32, 1363-1371.

Lyman, J. \& Fleming, R. H. (1940). Composition of sea water. J Mar Res 3, 134-146.

Mesbah, M., Premachandran, U. \& Whitman, W. B. (1989). Precise measurement of the $\mathrm{G}+\mathrm{C}$ content of deoxyribonucleic acid by highperformance liquid chromatography. Int J Syst Bacteriol 39, 159-167.

Mincer, T. J., Jensen, P. R., Kauffman, C. A. \& Fenical, W. (2002). Widespread and persistent populations of a major new marine actinomycete taxon in ocean sediments. Appl Environ Microbiol 68, 5005-5011.

Minnikin, D. E., O’Donnell, A. G., Goodfellow, M., Alderson, G., Athalye, M., Schaal, A. \& Parlett, J. H. (1984). An integrated procedure for the extraction of bacterial isoprenoid quinones and polar lipids. J Microbiol Methods 2, 233-241.

Pridham, T. C., Hesseltine, C. W. \& Benedict, R. G. (1958). A guide for the classification of streptomycetes according to selected groups; placement of strains in morphological sections. Appl Microbiol 6, 5279.

Scheuermayer, M., Gulder, T., Bringmann, G. \& Hentschel, U. (2006). Rubritalea marina gen. nov., sp. nov., a marine representative of the phylum 'Verrucomicrobia', isolated from a sponge (Porifera). Int J Syst Evol Microbiol 56, 2119-2124.

Shirling, E. B. \& Gottlieb, D. (1966). Methods for characterization of Streptomyces species. Int J Syst Bacteriol 16, 313-340.

Shirling, E. B. \& Gottlieb, D. (1968a). Cooperative description of type cultures of Streptomyces. II. Species descriptions from first study. Int $J$ Syst Bacteriol 18, 69-189.

Shirling, E. B. \& Gottlieb, D. (1968b). Cooperative description of type cultures of Streptomyces. III. Additional species descriptions from first and second studies. Int J Syst Bacteriol 18, 279-392.

Shirling, E. B. \& Gottlieb, D. (1972). Cooperative description of type strains of Streptomyces. V. Additional descriptions. Int J Syst Bacteriol 22, 265-394.

Staneck, J. L. \& Roberts, G. D. (1974). Simplified approach to identification of aerobic actinomycetes by thin-layer chromatography. Appl Microbiol 28, 226-231. 
Tamaoka, J. \& Komagata, K. (1984). Determination of DNA base composition by reversed-phase high-performance liquid chromatography. FEMS Microbiol Lett 25, 125-128.

Waksman, S. A. \& Henrici, A. T. (1943). The nomenclature and classification of the actinomycetes. J Bacteriol 46, 337-341.
Wayne, L. G., Brenner, D. J., Colwell, R. R., Grimont, P. A. D., Kandler, O., Krichevsky, M. I., Moore, L. H., Moore, W. E. C., Murray, R. G. E. \& other authors (1987). International Committee on Systematic Bacteriology. Report of the ad hoc committee on reconciliation of approaches to bacterial systematics. Int J Syst Bacteriol 37, 463-464. 